\title{
LIVING AND WORKING BENEATH THE SEA - NEXT APPROACH
}

\begin{abstract}
The idea of living beneath the sea is very new if compared with millennia of shipping activity. In fact, ocean surface was considered mainly as medium suitable for transport of persons and goods as well as aggression and robbery. More practical attempts to live "on" the water surface are limited to well protected internal waters.

The presented concept of "an underwater-above water accommodation, especially for residential purposes" proposes a possible solution. It was developed under the name of "Water Discus". To some extent it is a response to expressed requirements of potential operators as well ideas of European Commision regarding development of the "blue economy" (doc COM (2014) 254). Several basic research and design experiments were required to achieve current understanding of the concept requirements.
\end{abstract}

Keywords: living beneath the sea, "blue economy", underwater accommodation

\section{INTRODUCTION}

The idea of living beneath the sea is very new if compared with millennia of shipping activity. In fact, ocean surface was considered mainly as medium suitable for transport of persons and goods as well as aggression and robbery. More practical attempts to live "on" the water surface are limited to well protected internal waters. Idea of "men living beneath the sea" was born during dark days of World War II when scuba diving technology was developed practically. Tether-less diving apparatus "for everybody" allowed for mass scale contact with underwater environment and for widely understood exploration and pleasure. New capabilities crated also new expectations. The following next two decades witnessed fierce development of manned marine technology.
Beside manned submersibles, several hyperbaric habitats were developed and tested at sea. Finally, whole submarine towns were proposed. The process proved that available technology is adequately advanced to assure safety. At the same time it has become apparent that proposed solutions are too expensive to assure commercial feasibility. It has also indicated importance of psychological issues that need to be considered while developing a manned system to be used in strange environments. A very comprehensive summary of these achievements can be found in literature [1]. Fifty years later, ideas regarding living and working beneath the sea are even more futuristic than they were before. The presented concept of "an underwater-above water accommodation, especially for residential purposes" proposes a possible 
solution. It was developed under the name of "Water Discus". To some extent it is a response to expressed requirements of potential operators as well ideas of European Commision regarding development of the "blue economy" (doc COM (2014) 254). Several basic research and design experiments were required to achieve current understanding of the concept requirements.

\section{GENERAL CHARACTERISTICS OF THE WATER DISCUS CONCEPT}

The Water Discus (WD) is a novel-type underwater accommodation designed for coastal, shallow water areas. The WD is a manned, floating structure (barge) that can be self-propelled or towed and temporarily anchored to the bottom or a bottom fixed foundation. The WD is not „a passenger submersible craft". It's submerged accommodation part (Water Disc) has a constant connection with the part located above the water level. The solution assures permanent atmospheric air ventilation and several independent escape routes. The main idea behind the concept of the WD is to create an environment that will allow users to stay underwater for an unlimited period of time and enjoy the views of the surrounding marine life (the coral reef) through the panoramic windows. In addition, WD aims to offer facilities for various underwater research activities.

The WD complex consists of three basic components:

1. A movable unit called Float that contains an underwater accommodation called the Water Disc,

2. A fixed unit called the Air Disc,

3. A Support of the Air Disk composed of a few legs fixed into a foundation structure.

The components are separate structures connected by means of flexible hoses and cables to allow relative vertical movements.

\section{DESCRIPTION OF THE WD UNIT}

\section{THE FLOAT}

The Float is the basic element of the WD concept. It is composed of the Water Disc, a central vertical communication shaft and a ballast tank. The Water Disc provides underwater accommodation to the inhabitants or visitors that are interested in exploration of external marine environment. It is being submerged using water ballast pumped into the ballast tank. The water ballast is used to add as much weight to the Water Disc as needed to exceed its buoyancy, allowing it to submerge to the sea bottom. It is not submerged permanently as in a case of hydro-technical structure. The Water Disc can be either surfaced or submerged depending on the amount of water in the ballast tank. Whenever necessary, release of the water ballast will make the Water Disc positively buoyant, allowing it to automatically rise to the surface. An option to rotate the underwater disc 360 degrees is another innovative and interesting solution considered in the WD concept. Thanks to the rotation capability, every user of the underwater accommodation can admire the scenery changing behind the windows. The rotational movement is not quick enough to be actually felt by those staying in the Water Disc.

In principle, the float can be operated on its own. When installed at a location, the ballasted Float is sucked into sediments or a cavity prepared in a rock (concrete foundation). However, in such a mode of operation it would require substantial support during installation and maintenance. Large barges and heavy cranes are required. It is mainly due to stability problems during towing and submerging.

In the basic configuration the two-deck underwater Water Disk has an external diameter of approximately $30 \mathrm{~m}$. It can be utilized for various purposes. In the considered example, it contains rooms of an underwater hotel, daily visitor space, lobby, bars and theme exhibition.

Below the lowest deck of the Water Disc, extends a heavy stiffened structure that forms a suction skirt or caisson. The

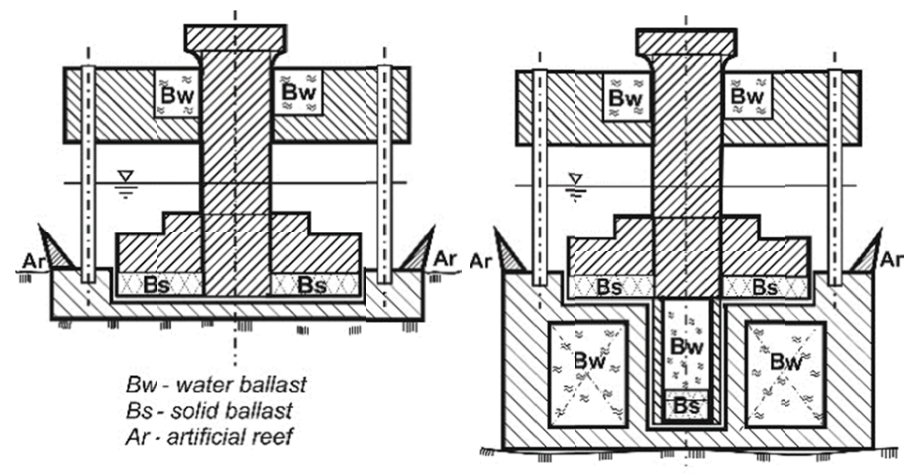

a

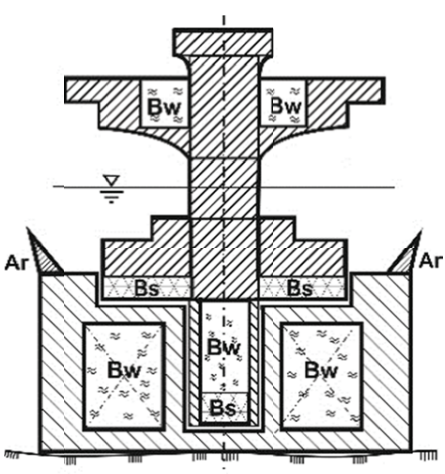

C

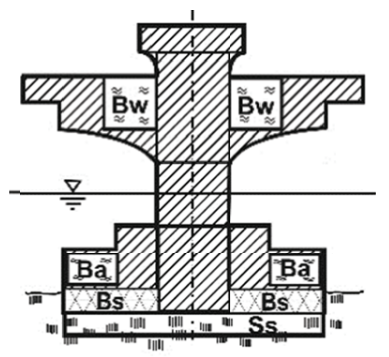

SS - suction skirt $\mathrm{Ba}$ - additional water ballast

d

Fig. 1 Configurations of the WD units depending on water depth and space requirements.

$a$ - Basic configuration for $10 \mathrm{~m}$ water depth, surfacing capability; $b$-Basic configuration for 10-30 $\mathrm{m}$ water depth, surfacing capability; $c$ - Reduced configuration for 20-30 $\mathrm{m}$ water depth, no legs, surfacing capability; $d$ - Minimal configuration for $10 \mathrm{~m}$ water depth, no legs, no surfacing 
suction skirt can be sucked into bottom sediments or placed in the prepared cavity. It is important to seal the space below the suction skirt to stop penetration of the pressure field into the caisson. Positive pressure below the suction skirt can move the Float up-wards.

At the center of the Water Disc structure there is a cylindrical shell of the communication tower (shaft). It begins some $3 \mathrm{~m}$ below the sea bottom (inside the caisson structure) and extends to $30 \mathrm{~m}$ above sea bottom (Deck 9) and $20 \mathrm{~m}$ above the water surface.

Structure of the communication tower provides mechanical connection and vertical separation of the Water Disc and the ballast tank. It also assures space for transfer of people between Air Disc and Water Disc by means of two personnel lifts and two separated and thermally insulated spiral staircases. Pipes and air ducts and cable trays built into the tower structure are used to transfer fluids and ventilation air, electric power and signals.

The ballast tank in form of a hexagonal structure is assembled on top of the communication tower. Various technical rooms are arranged inside the tank structure. The ballast tank structure of the self-operated Float can also be extended horizontally to form additional accommodation spaces that can be utilized for different purposes.

\section{THE AIR DISK AND THE SUPPORT}

The essential function of the Air Disk is to support of the operation of the float (Water Disc). In this role, the Air Disc is a mechanical guide for the float that allows for its safe vertical movement.
The Air Disc is suspended on the legs and provides stabilization of the Float at a selected location. It also houses majority of technical facilities required for the WD operations. Personnel rooms as well as additional guest rooms and other facilities can be arranged within the Air Disc also. Additional space can be added to the basic structure by application of the satellites, i.e. smaller discs that can accommodate a variety of facilities (bar, restaurant, spa), that are connected to the air disc.

Such a defined functions of the Air Disc can be extended to meet user requirements and imagination. This remark regards architectural appearance of the Air Disc also. Its shape can be arbitrary. In the case of the example application, the Air Disk consists of a three deck accommodation structure. Counting from the sea bottom, Deck 6 contains spaces available for visits, exhibitions, entrances to internal and external lifts, and visitor rest rooms. Deck 7 is devoted for a restaurant and bar with 200 seat. Space above Deck 8 contains a galley and various technical rooms and offices. It is covered with a roof shaped according to an architectural vision. In its center, the Air Disc structure large hexagonal cavity is arranged. This cavity contains the ballast tank of the float in basic operational condition.

To secure the Air Disc at a required level above the water surface $(6 \mathrm{~m}$ approximately) the support unit is required. It is composed of the legs and the foundation. The legs, penetrating and sliding inside the structure of the Air Disc, are permanently integrated with the foundation structure. The foundation, is a circular steel structure, rectangular in the cross section. It is divided by vertical walls to several caissons that are opened at the bottom. The foundation caisson begins

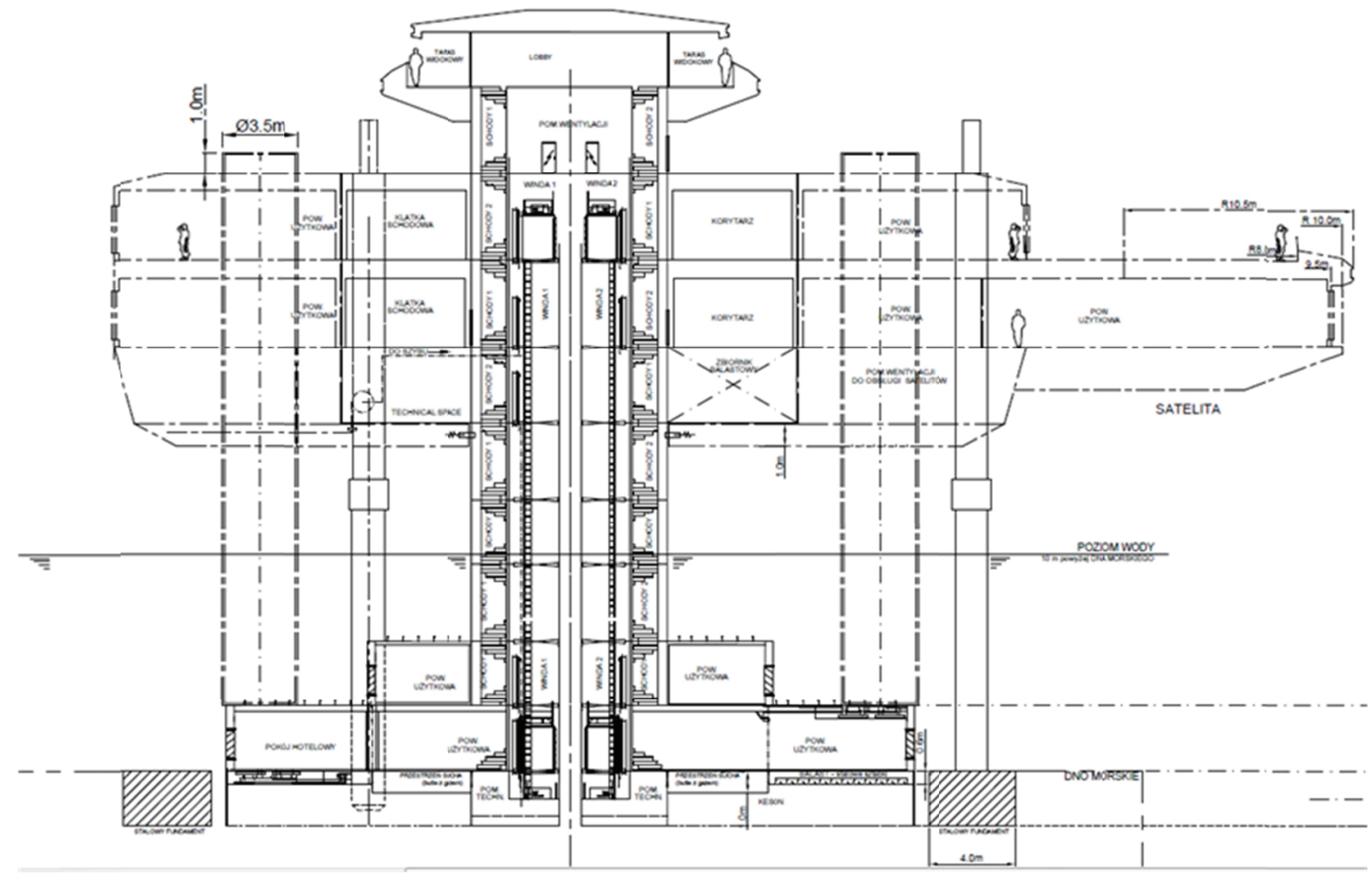

Fig. 2 Example General Plan of the Water Discus as proposed for the Ocean Science Exhibition Centre in Gdynia, Poland. 
it service to the WD unit from the moment of the launch. It is assumed, that the WD unit is assembled in a dry dock and towed out after assembly. To make it possible, the WD unit needs to be positively buoyant and have limited draft. The foundation caissons, while they are empty of water, provide buoyancy and stability of the WD unit while it is under tow to a given location or shipyard. Otherwise, additional buoyancy units of comparable size would be required. During short distance transport of the WD to an exploitation site location, the legs are in the up-rise position. While on the site, the legs are lowered using the support ballast system and by filling the support caissons with sea water. If local condition allows for, the foundation is than sucked into the bottom sediment. In a case of location with natural rocky bottom or a concrete foundation, the basement is sucked into the prepared cavity of required depth ( $3 \mathrm{~m}$ approximately). The foundation can be additionally fixed to the bottom or the concrete foundation to resist extreme weather conditions.

\section{DESIGN ASSUMPTIONS}

Safety of peoples involved in operation of the WD are of primary importance as for every manned system. Physical and mental comfort are also important but not critical in the case professional properly trained crew members. The mental comfort becomes a critically important factor when commercially manned activity (tourism) is considered. It was confirmed during experiments with the hyperbaric underwater habitats [1] that an underwater accommodation needs to be noiseless and motionless to allow guests or visitors "fall asleep". Such high level of mental safety is an apparent condition (requirement) to achieve a commercial success tourism industry. Safety of a technical system requires safe design, safe procurement, safe exploitation. To achieve high level of safety, the WD concept is developed and designed with extensive support of a ship classification society. It will also be procured according to classification rules and procedures.

Accidental safety issues considered for the WD regard mainly the following phenomena:

1. Safety during relocation ( when the WD unit is floating and under tow)

2. General damage due to collision with large ships

3. Local water leaks

4. Catastrophic flooding due to collapse of a large window

5. Fire and smoke

6. Typhoon (wind waves and current)

7. Tsunami or freak wave

8. Earthquake

Majority of the threats listed above can be assessed using statistical methods due to availability of the measurement and observation data (weather). The other ones need to be treated as accidents that cannot be predicted but must be considered in design and operation of the WD unit.

\section{LIMITING ENVIRONMENTAL CONDITIONS}

A specific purpose (application) and a considered location of the device are other important factors while considering commercial investment in this branch of the "blue economy". They indicate environmental constraints and define technical form of an object to be designed and operated safely.

Considering living and working beneath the sea, it is important to find reasonable ranges of environmental conditions that make such activities feasible without excessive costs, threats and discomfort to persons involved. After long evaluation, it was found that feasible compromise between various factors indicate the following ranges of environmental parameters for defined above underwater accommodation:
Water depth range
$8-30 \mathrm{~m}$
Water temperature range
$0-36^{\circ} \mathrm{C}$
Air temperature range
Sea current speed (maximum)
$-20-40{ }^{\circ} \mathrm{C}$
$1 \mathrm{~m} / \mathrm{s}$
Maximum wave height
(hundred year wave) $6 \mathrm{~m}$
Maximum tide amplitude $\quad 2 \mathrm{~m}$
Wind speed
up to $250 \mathrm{~km} / \mathrm{h}$
The parameters listed above, together with the compromise regarding minimum feasible dimensions define basic configuration of the WD unit. It is possible to operate the technology outside these limits but it increases costs beyond commercially acceptable level.

\section{PRINCIPAL PROBLEMS AND AREAS OF RESEARCH}

Ecological issues can be most serious obstacles in practical application of the WD technology as in any case of investment in a coastal area. For this reason, the WD technology is developed with widely understood ecology in mind. Minimum disturbance to the environment during the installation and exploitation as well as minimal feasible consumption and emission during exploitation are primary objectives of the developed configuration. Capability of compensation of possible disturbances to the local environment by means of structural and operational modifications is also studied.

High buoyancy of the submerged structure is a principal and does not always appreciate technical problem in design of a large underwater accommodation compartment. It is well illustrated by the figure valid for the basic configuration of the WD. It needs to be stressed, that the basic configuration is considered to be almost the smallest feasible for an underwater hotel application. Displacement of the submerged components of the basic configuration (the Water Disc of $30 \mathrm{~m}$ DIA) amounts to $5750 \mathrm{~m}^{3}$. The whole Float structure, optimized for expected mechanical loads, and outfitted with all required equipment weights 1700 tons (only). It means a force of some 5000 tons is required to submerge the Water Disc to the operational depth and stabilize it on the bottom. In the developed concept of the WD, the gravity force generated 
by a ballast weight is utilized. Sea water ballast and a solid ballast are used for this purpose. Amounts of both types of the ballast are optimized to allow the ballasting procedure that is described below.

When the Water Disc is finally submerged, its general strength and stability on the bottom become an issue. During calm weather it is mainly long term exposure to external pressure. Wind, wave and current loads dominate in adverse weather conditions. There are no established rules regarding design of a large volume structures located on bottom in coastal areas. In majority of cases, large marine structures that are designed to be operated at rough sea are raised high above the water surface. This well-established solution, in form of a platform elevated on slim legs, minimize hydrodynamic loads imposed by waves and currents. The idea to locate a large accommodation structure in shallow water is somehow an opposite approach. It means, that the majority of design, installation, operational rules assuring such a specific "seaworthiness" need to be developed in a full featured $\mathrm{R} \& \mathrm{D}$ process.

Third area of technical problems that were successfully solved in the development process regards exploitation without the need for extensive operational assistance. In a series of design experiment, a configuration allowing selfinstallation and refloating was searched for. Finally the device (WD) composed of the elements characterized above was developed. It assures operation without the need for the heavy cranes as a support. This substantially reduces installation and operational costs and reduces environmental impact of installation activity .

Other important subjects of research in WD development process are as follows:

- Psychological issues that require research regarding influence of considered solution are of mental comfort of visitors, crew and personnel.

- Optimization of the system for energy harvesting, transformation and storage.

- Selection of a materials and structure for underwater windows to maximize safety and reduce long term operational costs.

\section{INSTALLATION (BALLASTING) SEQUENCE OF THE WD UNIT AT THE LOCATION}

The following sequence of the ballasting concept of the WD allows to understand necessities and capabilities of the WD ballasting concept. It is illustrated on fig 2 .

1. The WD unit is floating at the surface using buoyancy of the Water Disc and foundation caissons connected to the legs that there are in raised position. In this state, the WD unit can be towed to a location site by tugs, relocated or towed to a shipyard for overhaul.

2. While at the location, the legs are lowered to the bottom and the leg caissons are sucked into the sediments. In this phase, the Air Disc is slightly immersed also so it needs to be watertight at the bottom part.
3. The Water Disc and part of the communication tower are submerged by pumping sea water into the ballast tank. The communication tower and the Air Disc are locked together.

4. The Air Disc is elevated to the required level by a buoyancy force as result of releasing of the ballast water. The Air Disc and the legs are locked together and the float can be released and submerged using water as ballast again.

5. If required the sequence can be repeated to elevate the Air Disc in $3 \mathrm{~m}$ steps to any higher level, say up to $12 \mathrm{~m}$ above water if required. Longer legs and higher vertical shaft are required accordingly.

6. While the Air Disc is blocked with the legs at a required height above the water surface, the floater (and the Water Disc) can be submerged or surfaced using the ballast. At the surfaced position personnel can leave the Water Disc accommodation using emergency hatches provided.

7. If the ballast tank and the caisson of the Water Disc are empty, the window frames of the Water Disc are above the water surface exposed for cleaning, repair or replacement.

\section{EMERGENCY ESCAPE ROUTES AND EQUIPMENT}

Submersion of the human occupied compartment below water surface combined with threats indicated above calls effective escape routes. These are required both to fulfill legal rules (SOLAS, local building safety laws) and to give safety awareness (filings) to the unit visitors.

These issues are the principal reason for the arrangement of the Water Disc and the communication tower. It assures possibly short escape routes from the submerged spaces in a case of emergency.

The design offers several alternative solutions available in various situations. They provide both real safety as well as psychological comfort for the visitors that need to feel perfectly safe.

In the case of operational configuration when the Water Disc is submerged, two thermally insulated personal lifts are used for vertical transport of peoples between the Air and the Water Discs. For emergency cases, two independent staircases are always available inside the Communication Tower. The staircases are sealed with fire doors, thermally insulated and ventilated (de-smoked) with separate blowers. As an alternative the external lifts operating between Deck 2 and Deck 6 can be utilized independently of above mentioned internal lifts. If the external lift is docked to the Water Disc it is also possible to use the ladder located inside the suspension shaft of the external lift as an emergency escape route.

In a case of extensive emergency, the Water Disc will be surfaced by release of the water ballast and blowing-out water from the suction caisson. This position allows for escape of the visitors and the staff using emergency hatches provided in ceilings of the Water Disc compartments. The hatch covers are 


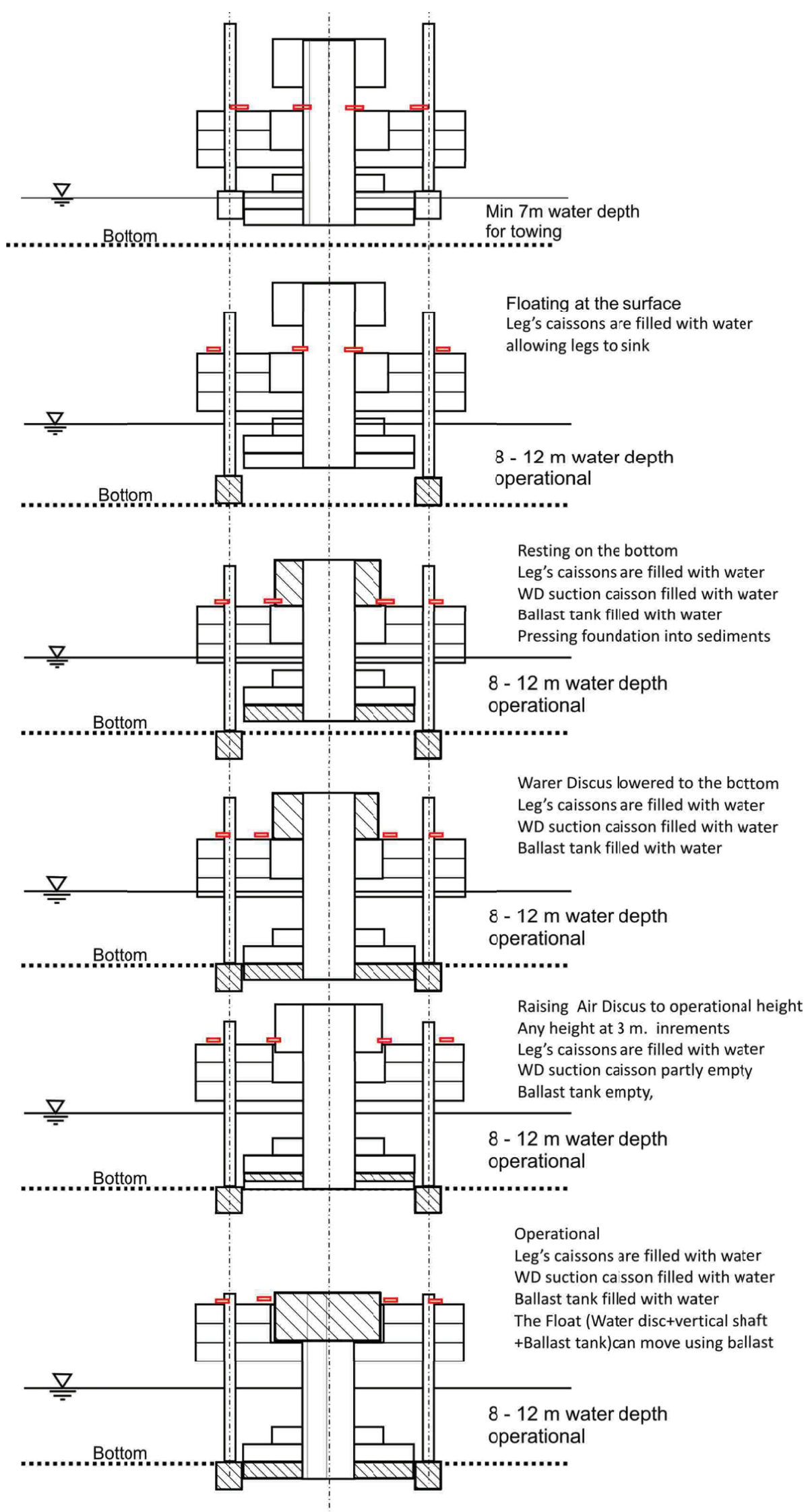

Fig. 3 Ballasting sequence of the Water Discus 
operated from both sides and can be opened when the hatch is above the water surface (when the Water Disc is surfaced).

\section{DESIGN METHODOLOGY}

Due to lack of established design rules of the WD, technology is developed using the first principle method. Various considered technical solutions and exploitation procedures are developed using value analyses. The value analyses are performed using criteria indicated in the sample table below. The criteria are indicated at the first line of table 1. The criteria given are the weight values ranging from 1 to 5 . The solutions proposed for every matter considered are given a score between 1 and 5. The results of the weight values and scores for all the criteria are summed and used for comparison of these solutions. In the considered example, the solutions are shown on fig 1 . In this case, solution 3 seems to be most appropriate for the assumed criteria and considered. The results of such a consideration are listed in the solution matrices for further study.

The sample given above regards a high level layer with qualitative evaluation. In fact, to compare all the features, detailed calculations or sub-analyzes are made, based on various possibly well-defined configurations.

Fuzzy logic algorithms are investigated as a tools that can facilitate a multi-criteria optimization of solutions that are considered within different layers.

\section{SUMMARY: WD - FRIEND OF THE COASTAL ENVIRONMENT}

After more than five years of the WD concept development, the eco-oriented advantages of the WD technology can be summarized as follows:

1. The Water Discus unit is designed to be environmentally friendly (minimum impact, during installation - no extensive engineering work required, low discharge, no spills).

2. The WD proposed for low latitudes is almost self-supplying (electrical energy) due to application of PV panel that cover the roof.

3. The Water Discus unit is designed to be the ultimate place of marine and ecological education (direct view of natural environment, exposition of solar panels and heat pumps at work), marine ecology oriented exhibitions.

4. The Water Disc is a perfect place for long term biological studies of the reef/coastal environment.

5. The Water Discus is a perfect place for long term studies of protection, restoration and creation of artificial reefs (corals).

6. Due to relocation capability, the Water Discus unit can be located at a given position and relocated if results of research performed indicate a better position (for example for better view or protection of natural coral reefs).

7. The externally stiffened structure of the Water Discus is a perfect artificial reef itself.

Table 1 The sample value analysis matrix as used to study WD unit location

\begin{tabular}{|c|c|c|c|c|c|c|c|c|c|}
\hline \multicolumn{10}{|c|}{ Considered matter - WD-WDR arrangement } \\
\hline & \multirow[t]{2}{*}{$\begin{array}{l}\text { Considered } \\
\text { solution }\end{array}$} & & $\begin{array}{c}\text { Personnel } \\
\text { safety }\end{array}$ & $\begin{array}{l}\text { Equipment } \\
\text { safety }\end{array}$ & Functionality & Aesthetics & Investment cost & $\begin{array}{c}\text { Through life } \\
\text { cost }\end{array}$ & \multirow[t]{2}{*}{ Total score } \\
\hline & & $\begin{array}{l}\text { Weight(W) } \\
\text { value (1-5) }\end{array}$ & 5 & 4 & 4 & 3 & 3 & 5 & \\
\hline & \multirow{2}{*}{$\begin{array}{l}\text { Solution } 1 \text { - } \\
\text { WDR to land } \\
\text { WD to land }\end{array}$} & $\begin{array}{c}\text { Score (S) } \\
(1-5)\end{array}$ & 5 & 3 & 4 & 4 & 5 & 5 & \multirow{2}{*}{102} \\
\hline & & Result (WxS) & 25 & 12 & 16 & 9 & 15 & 25 & \\
\hline \multirow{2}{*}{2} & \multirow{2}{*}{$\begin{array}{l}\text { Solution } 2 \text { - } \\
\text { WD to land } \\
\text { WDR to land }\end{array}$} & $\begin{array}{c}\text { Score (S) } \\
(1-5)\end{array}$ & 5 & 4 & 3 & 3 & 5 & 5 & \multirow{2}{*}{102} \\
\hline & & Result (WxS) & 25 & 16 & 12 & 9 & 15 & 25 & \\
\hline \multirow{2}{*}{3} & \multirow{2}{*}{$\begin{array}{l}\text { Solution } 3 \text { - } \\
\text { WDR to land } \\
\text { WD to WDR }\end{array}$} & $\begin{array}{c}\text { Score }(S) \\
(1-5)\end{array}$ & 5 & 5 & 5 & 5 & 5 & 5 & \multirow{2}{*}{136} \\
\hline & & Result (WxS) & 25 & 20 & 20 & 16 & 15 & 35 & \\
\hline \multirow{2}{*}{4} & \multirow{2}{*}{$\begin{array}{l}\text { Solution } 4 \text { - } \\
\text { WD to land } \\
\text { WDR to WD }\end{array}$} & $\begin{array}{c}\text { Score (S) } \\
(1-5)\end{array}$ & 5 & 4 & 4 & 5 & 5 & 5 & \multirow{2}{*}{127} \\
\hline & & Result (WxS) & 25 & 16 & 16 & 15 & 15 & 25 & \\
\hline
\end{tabular}

WD - Water Discus, WDR - Water Discus with reduced Air Disc 
8. Such complicated structures are appreciated by several fish spices. With plenty of cavities, it is a much better marine habitat than smooth rock or empty sea bottom.

9. The Water Discus being a substantial obstacle to waves can shelter natural reefs and other features if properly located.

10. The Water Discus is considered to be a typhoon shelter as it is glazed with double safety glass windows.

\section{LITERATURE}

1. Miller J. W., Koblick Ian G. "Working and living at sea", Best Publishing Company, 1995

2. Project report: „Przeprowadzenie badań oraz stworzenie konstrukcji obiektu podwodno - nadwodnego dla celów naukowych" (Research and development of a structure of the underwater-above water device for scientific purpose"), Project (IX.B.16)-Operation Program: Innovative Economy 2007-2013, PO IG 1.4.

3. Rowiński L., Zdrojewski J.: „Pomieszczenie podwodnonadwodne, zwłaszcza do celów mieszkalnych” („Underwater-above water accommodation for residential purposes”), Patent appl. P-392432 dated 17.09.2010;

4. Rowiński L., Zdrojewski J.: „Underwater-above water accommodation for residential purposes", United States Patent 9,010,266, dated 21.04.2015;

5. Rowiński L., Zdrojewski J.:"Urządzenie do nurkowania zwłaszcza do wód płytkich" (Device for diving, especially for shallow water), Patent PL 222384 dated 13.09.2012,

6. Rowiński L., Zdrojewski J.: Tytuł: "Pomieszczenie podwodno-nadwodne, zwłaszcza do celów mieszkalnych” („Underwater-above water accommodation for residential purposes”), Patent 224208 dated 17.04.2014, Patent appl. P-40076 dated 25.11.2013;

7. Rowiński L.: Tytuł: „Pomieszczenie podwodno-nadwodne, zwłaszcza do celów mieszkalnych” („Underwater-above water accommodation for residential purposes"), Patent appl. P-406227 dated 25.11.2013;

8. Rowiński L., Porala B., Wałamaniuk R. : "Urządzenie do transportu osób pod powierzchnią wody” („Device for transport of persons below water surface”) Patent appl. P-406871 dated 17.01.2014.

9. Rowiński L.: „Izobaryczne pomieszczenie podwodne, mieszkalne lub techniczne" ("Isobaric underwater accomodation for human occupancy or technical equipment") Patent appl. P-411357 dated 23.02.2015.

10. Rowiński L.: „Urządzenie do transportu pionowego i obsługi sportów wodnych" (Device for vertical transport and water sports), Patent appl. P- $\underline{411494}$ dated 05.03.2015.

11. Rowiński L.: „Dach ruchomy przestrzeni mieszkalnej lub technicznej" (articulated roof for human occupied and technical spaces", Patent appl. P- $\underline{411699}$ dated 23.03.2015.

12. Rowiński L.: „Statek do obserwacji podwodnych i nadwodnych” („A ship for underwater/ above water observation", industrial design Wp-23204, 05.03.2015, valid to 05.03 .2020

13. Rowiński L., Zagórski M.: „Urządzenie do transportu pionowego osób między pomieszczeniem nadwodnym i pomieszczeniem podwodnym” („Device for vertical transport of persons between underwater compartment and above water compartment"), Patent appl. P-417805, dated 01.07.2016

\section{CONTACT WITH THE AUTHOR}

Lech Rowiński

\author{
Gdańsk University of Technology \\ 11/12 Narutowicza St. \\ 80 - 233 Gdańsk \\ Poland
}

